\title{
建筑施工管理中绿色建筑施工管理的应用
}

\author{
王 明* \\ 云南嘉明建设工程有限公司, 云南 650000
}

\begin{abstract}
摘 要: 尽管我国地大物博, 但是一些资源仍然紧缺, 这就造成建筑工程在建设过程中往往会出现资源短缺的情 况, 在建设建筑工程时, 将绿色施工管理模式引入施工管理中是非常必要的。本文通过对绿色施工建筑管理模式进行 构思, 将绿色施工的理念引入到建筑施工管理中, 实现资源合理配置。
\end{abstract}

关键词：建筑施工管理; 绿色建筑施工管理; 绿色环保理念

\section{Application of Green Building Construction Management in Construction Management}

\author{
Ming Wang* \\ Yunnan Jiaming Construction Engineering Co., Ltd., Kunming 650000, Yunnan, China
}

\begin{abstract}
Although our country is rich in resources, but some resources are still in short supply, which leads to the shortage of resources in the construction process of construction engineering. Therefore, it is very necessary to introduce the green construction management mode into the construction management in the construction engineering. In this paper, through the conception of green construction building management mode, the concept of green construction is introduced into the construction management to realize the reasonable allocation of resources.
\end{abstract}

Keywords: Building construction management; Green building construction management; Green and environmental protection concept

\section{一、引言}

由于建筑工程的施工步骤十分繁琐, 涉及的环节也众多, 各个环节之间的联系非常紧密, 因此在施工开始之前, 要对施工流程进行缜密的安排管理 ${ }^{[1]}$ 。同时, 要在施工管理过程中融人绿色建筑管理的理念, 保证施工活动能够绿色 环保的进行。

\section{二、建筑施工管理当中的绿色施工管理重要性研究}

目前, 我国各行各业的发展都离不开绿色环保理念, 建筑行业作为资源消耗较大的一个行业, 在施工过程中更应 该融入绿色施工管理的理念。所谓的绿色施工管理, 不仅仅是保护环境, 更要在施工过程中做到资源合理分配降低对 环境污染物的排放 ${ }^{[2]}$ 。改变绿色施工的管理理念, 要在施工过程中使用绿色的施工技术, 摒弃传统的污染性比较强的 施工手段, 也要降低施工过程中对环境的污染排放, 对施工中产生的废弃物进行处理后再排放 ${ }^{[3]}$ 。另外, 建筑在施工 过程中也要尽可能地降低对能源的消耗量, 可以使用一些清洁环保的能源进行施工。

我国大力发展绿色持续发展的发展理念, 建筑行业想要长久的立足市场, 也要坚持走绿色发展理念, 不仅要节约 资源能源, 同时也要开发一些新型清洁能源。我国发展绿色管理理念, 主要是因为过去环境破坏对资源影响很大, 尽 管我国地大物博, 但是随着经济发展, 现成的资源捉襟见肘, 想要更好的达到持续发展, 就要合理规划资源配置, 同 时各行各业都要做到节能减排 ${ }^{[4]}$ 。建筑行业想要从根本上推动经济的发展, 首先要做到的是保护环境, 降低对环境的 污染, 只有这样才能促进自身的长久发展, 为社会经济发展作出更大的贡献。因此, 建筑行业在对施工进行管理中融 人绿色施工管理的理念是非常必要的。

*通讯作者: 王明, 1991年11月, 男, 汉族, 现任云南嘉明建设工程有限公司, 技术负责人, 初级工程师, 本 科。研究方向: 房屋建筑。 


\section{三、绿色施工技术在施工管理中的研究分析}

(一) 质量管理

建筑工程想要长久的发展下去, 首先要保证其质量安全, 保证建筑工程的质量, 稳定性需要施工单位制定一套合 理的管理体系 ${ }^{[5]}$ 。影响建筑工程质量安全的因素有很多, 不单单是依靠施工人员努力工作就能达到的, 为此施工单位 要根据建筑行业存在的风险及安全隐患, 提前制定一套应急措施，根据容易出现问题的方面，制定一套完善的质量监 管制度。

\section{(二) 进度管理}

施工在开始之前要对施工的各个环节进行评估，对需要利用到资源配置的环境，提前进行资源配置规划，避免在 施工过程中出现资源短缺的情况。同时也要监督施工人员在施工过程中节约使用资源, 避免出现过度浪费资源的情 况。管理人员在对物资能源进行分配时, 要根据各个施工环节的需求进行分配, 同时也要针对一些建筑施工环节设定 专门的绿色施工技术, 以长远角度来看质量不合格, 就会影响工程正常推进 ${ }^{[6]}$ 。施工进度方面, 有必要从人员安排和 组织方面考虑。人员分工的时候, 需要按照实际情况, 让所有人都能了解自己职责, 逐步实现每一个目标, 保障工程 整体效果与质量。

\section{(三) 成本管理}

由于建筑工程是一项耗资巨大的工程项目，因此在建筑工程进行施工之前要对其成本进行预算，在建筑施工过程 中使用绿色施工技术既能降低建筑项目的成本, 同时也为承办单位获得更大的利益 ${ }^{[7]}$ 。使用绿色施工技术, 不仅能够 节约资源, 降低施工成本, 同时也会降低对环境的危害。对于建筑工程来说, 在环境中排放污染物是常有的事情, 对 污染物进行处理也是一项耗资巨大的工程, 使用绿色环保施工技术可以降低施工过程中对环境的污染物排放量, 节约 施工成本，间接为企业谋得了更大的利益，促进了建筑行业的持续发展。

( 四) 安全管理

对于建筑工程来说, 确保施工过程的安全, 进展是非常重要的。在施工过程中使用一些新型能源进行施工, 不仅 能够降低对环境的污染, 减少污染排放量, 同时也对施工工人的健康起到一定的保护作用。在施工过程中要对参与危 险作业的施工人员, 进行安全防护, 只要保证施工工人的人身安全, 才能促进建筑行业的持续发展 ${ }^{[8]}$ 。另外, 一些工 人使用绿色施工技术，降低了对空气中甲醛等一些化学物质的排放，对施工工人的安全起到了一定的保护作用。

\section{四、施工管理视角下的绿色建筑施工管理创新研究}

目前, 建筑行业在我国市场上的发展速度非常迅速，已经成为了社会市场上的支柱产业，建筑业想要长久的发展 下去, 必须要在施工管理理念中, 加人绿色环保的施工理念。另外, 对于建筑企业来说, 管理人员必须意识到持续发 展理念, 对于建筑企业未来的发展有多重要, 只有走绿色施工发展的道路, 才能保障建筑企业的持续发展, 这就要求 管理人员在思想上重视绿色施工发展理念。想要发展绿色施工理念不能单纯的靠施工人员, 节能减排, 工作人员要在 管理层面创新施工技术，改变施工方案，将传统的施工管理制度摒弃，在进行施工管理时，坚持绿色发展理念 ${ }^{[9]}$ 。同 时, 也要在绿色施工管理过程中, 引人高新技术人才, 加强对施工技术的创新管理, 在传统的、耗能大的施工技术基 础上进行创新，在施工技术上引人绿色施工科技。

\section{五、绿色施工管理视角下的建筑施工管理创新}

当前建筑施工行业, 在市场上遭受着非常激烈的竞争, 想要使得建筑行业长久的立足市场, 必须引进新鲜的科技 人才, 通过人才管理来改变建筑施工的管理理念, 在施工管理层面引人绿色发展的理念。建筑行业想要将绿色施工管 理理念进行大范围的推广, 首先需要更新管理人员的管理理念, 要求管理人员摒弃传统的管理理念, 在对施工进行管 理时使用绿色施工管理的模式, 只有从管理层进行创新, 才能做到将绿色施工管理模式, 在行业内大范围推广 ${ }^{[10]}$ 。另 外, 建筑行业在进行建筑项目施工时, 也要引人一些高新技术, 只有引人一些新型的技术仪器设备, 才能使建筑业发 展做到真正的绿色生产。

\section{（一）加强能源管理}

推广绿色环保施工理念, 首先要在施工过程中加强对各种资源能源的管理力度, 在施工过程中不能肆意妄为的浪 费资源能源, 同时也要引人一些新型仪器设备, 将耗能较大的仪器设备进行淘汰。要注意对新引人的仪器设备进行后 期维修保护, 尽量降低对设备的耗损, 延长设备的使用寿命, 对于耗能大的仪器设备要及时进行淘汰。同时, 也要培 
养一些专业人才来对仪器设备进行操作，保证设备能够长久的使用下去。如图1为能源管理示意图。

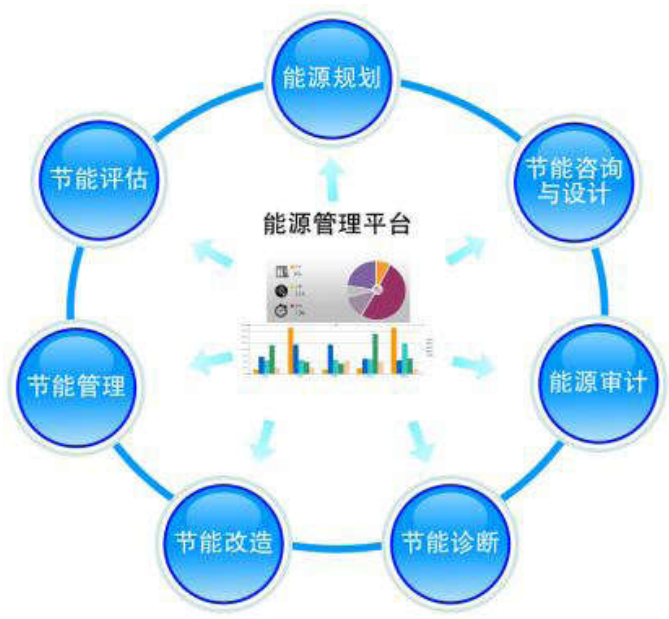

图1 能源管理示意图

\section{（二）妥善管理水资源}

在进行建筑施工时，避免不了使用水资源，而水资源作为我国的稀缺资源，在使用过程中要尽量降低浪费。对使 用过的水资源要进行回收处理, 保证水资源在建筑施工过程中发挥起最大作用。在对水资源进行储备时, 要对水资 源储备库进行合理改进，不要使水资源受到污染，对使用过的水资源要做好回收处理，设置专门的回收处理场地。同 时, 也可以对施工现场的雨水进行收集, 在建筑施工开展过程中使用。对于施工过程中产生的废水, 施工单位要负责 对废水进行处理, 使废水达到排放标准后再进行排放, 必要的话可以送到污水处理厂进行处理。如图2为水资源管理 示意图。

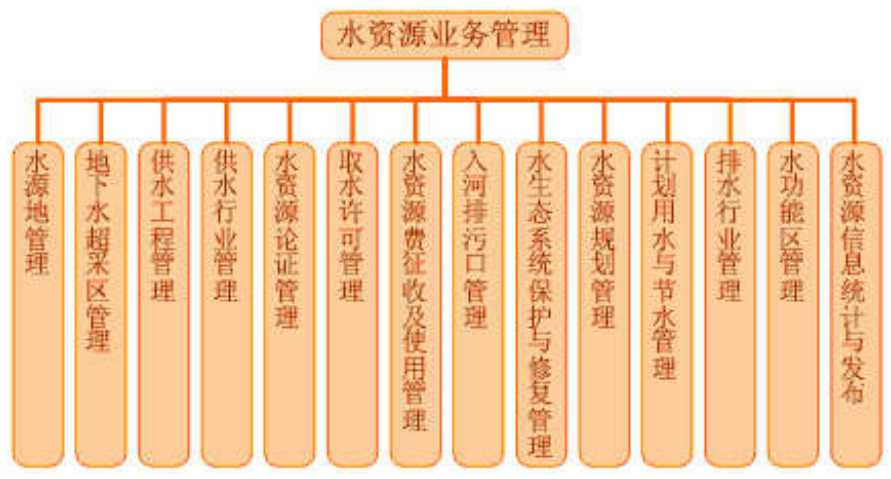

图2 水资源管理示意图

\section{（三）加强施工污染管理}

工程施工中，会产生非常多的污染物，有效管理污染物，才能体现绿色管理追求，实现工程可持续发展。

1. 控制泥浆

泥浆污染来自基础和土方工程。污染问题的防治可以选择相应的工程工艺或使用人工措施治理。此外, 光污染控 制同样是很重要的工作。应尽可能减少电焊亮光。

2. 加强噪音控制

工程中的噪音来自建筑机械以及运输车辆, 施工期间的噪音特点为, 有着比较集中的时间, 位置变化比较突出。 该问题的处理, 应加强宣传, 让公众了解噪音情况。施工单位应做好管理, 绝不能夜晚施工, 影响周围居民休息。尽 可能使用噪音比较小的机械设备, 做好噪音监测工作。

3. 必须重视固体废弃物管理工作

绝大多数工程中的固体废弃物都能回收使用。在工程施工期间, 应根据情况制定重复利用固体废弃物的方案, 减 少浪费，保障工程稳定施工。图片3为施工污染现场。 


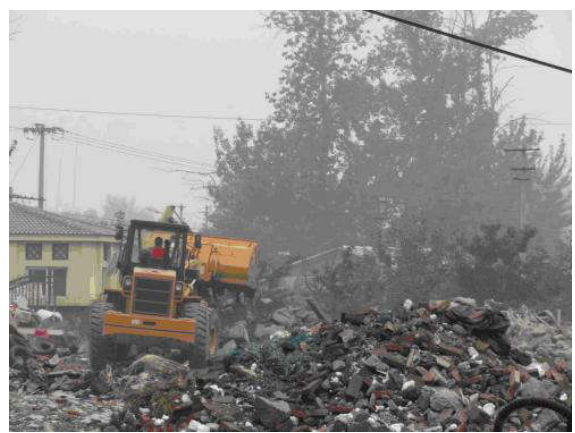

图3 施工污染现场

\section{六、结语}

综上所述, 我们可以了解到, 在建筑施工过程中使用绿色施工理念是非常重要的。绿色施工技术不仅能帮助企业 持续发展, 降低对环境的污染排放, 也是对国家生态资源的一种保护形式。在施工过程中建筑企业尽量将降低污染排 放, 将能源利用率做到最大, 既是对企业自身的一种发展理念, 同时也是为国家资源保护作出了贡献。绿色施工建设 管理理念不仅是建筑行业必须坚持的发展模式，同时也应该被各行各业所借鉴。

\section{参考文献:}

[1]朱明飞.建筑工程绿色施工技术的现场实施及动态管理[J].中国房地产业, 2021(15):102.

[2]刘佳.绿色施工理念下的建筑工程管理模式创新研究 [J].建筑工程技术与设计, 2021(10):806.

[3]史平柱.建筑工程管理创新及绿色施工管理研究 [J].中国房地产业, 2021(13):123.

[4]赵欣.绿色施工理念下的建筑工程管理模式创新思考 [J].世界家苑, 2021(1):7.

[5]程杜铭.建筑工程绿色施工技术的现场实施及动态管理[J].江西建材, 2021(1):177,179.

[6]柴珊珊.绿色施工理念下的建筑工程管理模式创新思考[J].城镇建设, 2021(3):58.

[7]辛勇.建筑工程绿色施工技术的现场实施及动态管理分析[J].中国房地产业, 2021(2):107.

[8]苏海燕.基于建筑施工管理与绿色建筑施工管理的对比探讨[J].建筑技术开发, 2021,48(5):87-88.

[9]赵敏.绿色施工理念下的建筑工程管理模式创新探讨 [J].中国设备工程, 2020(3):191-192.

[10]任兴星.建筑工程管理创新及绿色施工管理[J].中国建筑装饰装修, 2020(2):98. 